\title{
$\beta$-lactamase-producing Gram-negative bacteria in an intensive care unit in southern Brazil
}

\author{
Clariana Akemi Kariya Leite, Karina Yoshimi Oizumi, Katiany Rizzieri Caleffi-Ferracioli, Regiane \\ Bertin de Lima Scodro, Rubia Andreia Falleiros de Pádua, Rosilene Fressatti Cardoso, Claudia \\ Terencio Agostinho Pires, Vera Lucia Dias Siqueira*
}

\begin{abstract}
Laboratory of Medical Bacteriology, Department of Clinical Analysis and Biomedicine, State University of Maringa, PR, Brazil
\end{abstract}

\begin{abstract}
The present study evaluated the antimicrobial susceptibility profile, $\beta$-lactamase production, and genetic diversity of Enterobacteriaceae, Pseudomonas aeruginosa, and Acinetobacter spp. using phenotypic identification, antimicrobial susceptibility testing, and $\beta$-lactamase phenotypic detection. Isolates were obtained from patients in an intensive care unit in a hospital in southern Brazil. Bacterial genomic DNA was extracted, followed by the genotypic detection of carbapenemases and enterobacterial repetitive intergenic consensus-polymerase chain reaction (ERIC-PCR). Fifty-six isolates (26 Klebsiella pneumoniae, five Escherichia coli, three Enterobacter aerogenes, nine P. aeruginosa, and 13 Acinetobacter spp.) were evaluated. The phenotypic extended spectrum $\beta$-lactamase (ESBL) test was positive in $53.8 \%$ of the K. pneumoniae isolates, $100.0 \%$ of the E. coli isolates, and $100.0 \%$ of the E. aerogenes isolates. Phenotypic and genotypic testing of $K$. pneumoniae carbapenemase (KPC) was positive in $50.0 \%$ of the K. pneumoniae isolates. Phenotypic and genotypic testing showed that none of the P. aeruginosa or Acinetobacter spp. isolates were positive for metallo- $\beta$-lactamase (MBL). The $b l a_{\mathrm{OxA}}$ gene was detected only in Acinetobacter spp. The lowest genetic diversity, determined by ERIC-PCR, was observed among the KPC-producing K. pneumoniae isolates and OXA-producing Acinetobacter spp. isolates, indicating the inadequate dissemination control of multidrug-resistant bacteria in this hospital environment.
\end{abstract}

Uniterms: Enterobacteriaceae. Pseudomonas aeruginosa. Acinetobacter spp. Antimicrobial resistance. Beta-lactamases. Bacterial typing. Intensive Care Unit/study/Brazil. Drug-resistant bacteria.

\section{INTRODUCTION}

Healthcare-associated infections are among the leading causes of morbidity and mortality in patients and are associated with higher treatment costs (Sydnor, Perl, 2011). Some studies have reported the importance of controlling nosocomial infection to reduce the number of these infections, which provides economic benefits (Gastmeier et al., 2006; Rosenthal, Maki, Graves, 2008; Landelle, Marimuthu, Harbarth, 2014).

Pseudomonas aeruginosa, Acinetobacter spp., and some members of the Enterobacteriaceae family are often involved in nosocomial infections (Mendes et al., 2005). For decades, extended-spectrum $\beta$-lactamase

\footnotetext{
*Correspondence: Laboratório de Bacteriologia Médica. Departamento de Análises Clínicas e Biomedicina. Universidade Estadual de Maringá, Avenida Colombo, 5790, 87020-900, Maringá Paraná, Brasil. Tel./Fax: +5544 3011-5375. E- mail: vldsiqueira@gmail.com
}

(ESBL)-producing Gram-negative bacteria have been an important cause of therapy failure. Carbapenems are usually the only available treatment option (McGowan, 2006). However, carbapenemase-producing Gramnegative pathogens, such as Klebsiella pneumoniae carbapenemase (KPC) and metallo- $\beta$-lactamase (MBL), are resistant to all available antimicrobial agents, including carbapenems, and have emerged in most hospitals worldwide (Zavascki et al., 2009; Nordmann, Naas, Poirel, 2011; Toledo et al., 2012; Maragakis, 2010; Cherkaoui et al., 2014).

The emergence of multidrug resistance has hampered and limited treatment options. Prompt and adequate treatment is crucial. The management of these life-threatening infections and treatment decisions should be guided by reliable antimicrobial susceptibility testing (Gagliotti et al., 2014; Tängdén, Giske, 2015).

The increase in multidrug-resistant pathogens has 
occurred concomitantly with a drastic reduction of the discovery and development of new antimicrobial agents, making these infections more difficult to control (Cassir, Rolain, Brouqui, 2014).

The identification of microorganisms that are involved in nosocomial infections and knowledge of their antimicrobial resistance profiles can guide physicians in choosing the appropriate therapy, playing a key role in epidemiology (Stuart, Leverstein-Van Hall, 2010).

The present study evaluated the antimicrobial susceptibility profile, $\beta$-lactamase production, and genetic diversity of Enterobacteriaceae, P. aeruginosa, and Acinetobacter spp. isolates that were obtained from patients in an intensive care unit (ICU) in a hospital in southern Brazil from March 2012 to August 2013.

\section{METHODS}

Enterobacteriaceae and non-glucose-fermenting Gram-negative (P. aeruginosa and Acinetobacter spp.) isolates were obtained from patients in an ICU in a hospital in southern Brazil, from March 2012 to August 2013. Only one isolate from each patient was selected and stored at -80 ${ }^{\circ} \mathrm{C}$ in the Laboratory of Medical Bacteriology, Department of Clinical Analysis and Biomedicine, State University of Maringa. No personal data were taken from patients, the privacy was guaranteed as well the law concerning research with humans (Resolution 466/2012 Brazil National Health Council, Health Ministry). Phenotypic identification and antimicrobial susceptibility testing (AST) were carried out by AUTO-SCAN-4 automated system (Siemens Microscan, Inc., Deerfield, IL, USA). The susceptibility testing was interpreted according to the criteria of the Clinical and Laboratory Standards Institute (CLSI, 2015).

Klebsiella pneumoniae and Escherichia coli isolates were tested to ESBL production by confirmatory phenotypic test (CLSI, 2015), and Enterobacter aerogenes isolates by disk approximation test (Tumbarello et al., 2004), using cefepime disk (30 mg, Oxoid Basingstoke, England). $K$. pneumoniae $\mathrm{ATCC}^{\circledR} 700603$ and E. coli $\mathrm{ATCC}^{\circledR} 25922$ were used as positive and negative controls, respectively.

KPC phenotypic detection was carried out in Enterobacteriaceae, which had Minimal Inhibitory Concentration (MIC) $\geq 0.5 \mu \mathrm{g} / \mathrm{mL}$ to meropenem by the modified Hodge test (MHT) (CLSI, 2015). K. pneumoniae isolates with and without bla $_{K P C}$ gene, kindly provided by the Central Laboratory of Parana (LACEN) were used as control.

Ceftazidime-resistant $P$. aeruginosa and Acinetobacter spp. isolates were evaluated for the presence of MBL by disc-approximation test, using 2-mercaptopropionic acid (2-MPA, Acros, New Jersey, USA) and EDTA (Invitrogen, Carlsbad, USA) (Arakawa et al., 2000). IMP-1-producing A. baumannii (A-3227) (Gales et al., 2003b) and P. aeruginosa ATCC ${ }^{\circledR}$ 27853 were used as positive and negative controls, respectively.

Detection of $b l a_{\mathrm{KPC}}, b l a_{\mathrm{OXA}}, b l a_{\mathrm{SPM}}, b l a_{\mathrm{IMP}}, b l a_{\mathrm{GIM},}$ and $b l a_{\mathrm{SIM}} \beta$-lactamase genes were performed by PCR using Veriti 96-well thermal cycler instrument (Applied Biosystems at Life Technologies, Foster City, CA) and AmpliTaq Gold ${ }^{\circledR}$ PCR master mix (Applied Biosystems at Life Technologies, Hammonton, NJ). The primer sequences and amplicon sizes are shown in Table I.

All isolates were fingerprinted using enterobacterial repetitive intergenic consensus-polymerase chain reaction (ERIC-PCR) (Versalovic, Koeuth, Lupski, 1991). Bacterial genomic DNA was extracted by the heat boil method from the overnight bacterial growth (Swanenburg et al., 1998). The PCRs were performed using primers ERIC1R (5'-ATGTAAGCTCCTGGGGATTCAC-3') and ERIC2 (5'-AAGTAAGTGACTGGGGTGAGCG-3'), as described by Szczuka and Kaznowski (2004). The

ERIC-PCR fragments obtained were examined by electrophoresis in $2 \%$ agarose gels and stained with ethidium bromide. The spectral band analysis on agarose gel was performed using BioNumerics software (version 4.45, Applied Maths, Sint-Martens-Latem, Belgium). The dendrogram was constructed using the Dice coefficient, and the phylogenetic distance was determined using the Unweighted Pair Group Method with Arithmetic Mean algorithm (Sneath, Sokal, 1973). Isolates with $\geq 90 \%$ similarity were considered closely related.

\section{RESULTS}

The studied institution is a small-size public hospital with 10 adult's ICU beds and pediatric. Fifty-six isolates (26 K. pneumoniae, five E. coli, three E. aerogenes, nine P. aeruginosa, and 13 Acinetobacter spp.) were tested for susceptibility profile and genotyped.

Resistance profiles for all isolates are shown in Table II. Most of the Acinetobacter spp. and K. pneumonia isolates were resistance to carbapenems.

Among Enterobacteriaceae, the phenotypic ESBL test was positive in $53.8 \%(14 / 26)$ of the $K$. pneumonia isolates, $100.0 \%(5 / 5)$ of the $E$. coli isolates, and $100.0 \%$ $(3 / 3)$ of the E. aerogenes isolates. The phenotypic KPC test was positive in $50.0 \%(13 / 26)$ of the $K$. pneumoniae isolates. The KPC enzyme was not detected in the $E$. coli or $E$. aerogenes isolates. Most of the KPC-producing $K$. 
TABLE I - Oligonucleotides used in the PCR reactions

\begin{tabular}{|c|c|c|c|}
\hline Primer $^{\mathrm{a}}$ & Sequence (5'-3') & Amplicon size (bp) & Reference \\
\hline $\begin{array}{l}\mathrm{KPC}(\mathrm{F}) \\
\mathrm{KPC}(\mathrm{R})\end{array}$ & $\begin{array}{l}\text { ATGTCACTGTATCGCCGTCT } \\
\text { TTTTCAGAGCCTTACTGCCC }\end{array}$ & 893 & Poirel et al., 2011 \\
\hline $\begin{array}{l}\text { GIM-1(F) } \\
\text { GIM-1(R) }\end{array}$ & $\begin{array}{l}\text { AGAACCTTGACCGAACGCAG } \\
\text { ACTCATGACTCCTCACGAGC }\end{array}$ & 753 & Castanheira et al., 2004 \\
\hline $\begin{array}{l}\text { IMP-1(F) } \\
\text { IMP-1(R) }\end{array}$ & $\begin{array}{l}\text { TGAGCAAGTTATCTGTATTC } \\
\text { TTAGTTGCTTGGTTTTGATG }\end{array}$ & 740 & Yan et al., 2001 \\
\hline $\begin{array}{l}\text { SIM-1(F) } \\
\text { SIM-1(R) }\end{array}$ & $\begin{array}{c}\text { AGAACCTTGACCGAACGCAG } \\
\text { ACTCATGACTCCTCACGAGG }\end{array}$ & 570 & Poirel et al., 2011 \\
\hline $\begin{array}{l}\text { SPM-1(F) } \\
\text { SPM-1(R) }\end{array}$ & $\begin{array}{l}\text { CCTACAATCTAACGGCGACC } \\
\text { TCGCCGTGTCCAGGTATAAC }\end{array}$ & 650 & Gales et al., 2003a \\
\hline $\begin{array}{l}\text { OXA-23(F) } \\
\text { OXA-23(R) }\end{array}$ & $\begin{array}{c}\text { GATCGGATTGGAGAACCAGA } \\
\text { ATTTCTGACCGAATTTCCAT }\end{array}$ & 501 & Woodford et al., 2006 \\
\hline $\begin{array}{l}\text { OXA-24(F) } \\
\text { OXA-24(R) }\end{array}$ & $\begin{array}{l}\text { GGTTAGTTGGCCCCCTTAAA } \\
\text { AGTTGAGCGAAAAGGGGATT }\end{array}$ & 246 & Woodford et al., 2006 \\
\hline $\begin{array}{l}\text { OXA-51(F) } \\
\text { OXA-51(R) }\end{array}$ & $\begin{array}{l}\text { TAATGCTTTGATCGGCCTTG } \\
\text { TGGATTGCACTTCATCTTGG }\end{array}$ & 353 & Woodford et al., 2006 \\
\hline
\end{tabular}

${ }^{\mathrm{a}} \mathrm{F}$, sense primer; $\mathrm{R}$, antisense primer

TABLE II - Antimicrobial resistance profile of Gram-negative bacteria isolated from patients in an ICU in southern Brazil, from March 2012 to August 2013

\begin{tabular}{|c|c|c|c|c|c|}
\hline \multirow[b]{2}{*}{ Antimicrobials } & \multicolumn{5}{|c|}{$\%$ resistant isolates } \\
\hline & $\begin{array}{c}\text { K. pneumoniae } \\
(\mathrm{n}=\mathbf{2 6})\end{array}$ & $\begin{array}{l}\text { E. coli } \\
(\mathrm{n}=5)\end{array}$ & $\begin{array}{c}\text { E. aerogenes } \\
(\mathrm{n}=\mathbf{3})\end{array}$ & $\begin{array}{c}\text { P. aeruginosa } \\
(\mathrm{n}=9)\end{array}$ & $\begin{array}{c}\text { Acinetobacter spp. } \\
(\mathrm{n}=13)\end{array}$ \\
\hline Cefuroxime & 100.0 & 100.0 & 100.0 & NP & NP \\
\hline Cefepime & 100.0 & 100.0 & 100.0 & 44.3 & 100.0 \\
\hline Ceftazidime & 96.1 & 100.0 & 66.6 & 77.7 & 84.6 \\
\hline Ciprofloxacin & 100.0 & 60.0 & 66.6 & 22.2 & 100.0 \\
\hline Imipenem & 50.0 & 0.0 & 0.0 & 22.2 & 84.6 \\
\hline Meropenem & 50.0 & 0.0 & 0.0 & 22.2 & 84.6 \\
\hline Ertapenem & 73.1 & 0.0 & 0.0 & NP & NP \\
\hline
\end{tabular}

NP: Not Performed.

pneumoniae isolates were resistant to all of the antibiotics tested (only $15.4 \%$ were sensitive to amikacin). Among the non-KPC-producing K. pneumoniae isolates, $46.1 \%$ were resistant to ertapenem. All of the KPC-producing K. pneumoniae isolates, detected by the MHT test, were positive for the $b l a_{\mathrm{KPC}}$ gene. None of the other Enterobacteriaceae isolates were positive for bla $_{\mathrm{KPC}}$.

None of the ceftazidime-resistant $P$. aeruginosa isolates or Acinetobacter spp. isolates were positive for MBL. The $b l a_{\mathrm{KPC}}, b l a_{\mathrm{SPM}}, b l a_{\mathrm{IMP}}, b l a_{\mathrm{GIM}}$, and $b l a_{\mathrm{SIM}}$ genes were not detected in the P. aeruginosa or Acinetobacter spp. isolates that were resistant to ceftazidime. The $b l a_{\text {OXA }}$ genes were detected in Acinetobacter spp. isolates, in which $100.0 \%(13 / 13)$ were positive for $b l a_{\text {OXA-51 }}$ and $84.6 \%(11 / 13)$ were positive for $b a_{\text {OXA-23 }}$.

The ERIC-PCR analysis of $26 \mathrm{~K}$. pneumoniae isolates revealed DNA band patterns that could differentiate four isolates, and $84.61 \%(22 / 26)$ of the $K$. pneumoniae isolates formed three clusters, with four, eight, and 10 isolates each. For the five $E$. coli isolates, three were unique, and $2 / 5(40 \%)$ were clustered. The three $E$. aerogenes isolates presented unique profiles. The nine $P$. aeruginosa isolates could be differentiated into one cluster with four isolates $(4 / 9$ [44.44\%]) and five isolates with unique patterns. For Acinetobacter spp. isolates, 10/13 $(76.92 \%)$ were clustered, and three had unique patterns. 


\section{DISCUSSION}

Although sparse official data have been published, bacterial resistance in Brazil is a major challenge to antimicrobial therapy, especially in the southern and southeastern regions (Rossi, 2011; Toledo et al., 2012). The present study detected high rates of resistance to thirdand fourth-generation cephalosporins and a concerning increase in resistance to carbapenems in Gram-negative bacilli that were isolated from patients in an ICU in a hospital in southern Brazil. In Enterobacteriaceae, ESBL production is a decisive mechanism that determines resistance to broad-spectrum cephalosporins. Recent studies by Jones et al. (2013), Bonelli, Moreira, and Picão, (2014), and Nogueira et al. (2014) corroborate our findings, indicating that this mechanism of resistance is especially common in K. pneumoniae, E. coli, and Enterobacter spp. in Brazil, with important implications for decisions regarding adequate antimicrobial therapy. In the present study, ESBL production was high in $K$. pneumoniae. Because the co-production of KPC prevents interpretations of the results of ESBL phenotypic testing (Poulou et al., 2014), we did not test for ESBL genes.

The production of carbapenemases was important for antimicrobial resistance in the Enterobacteriaceae and non-glucose-fermenting Gram-negative isolates. The predominant carbapenemases include New Delhi metallo- $\beta$-lactamases (NDM), Oxacillinases (OXA), Verona integron-encoded metallo- $\beta$-lactamase (VIM), Imipenemase (IMP), and KPC, which are encoded by the genes $b l a_{\mathrm{NDM}}, b l a_{O X A}, b l a_{\mathrm{VIM}}, b l a_{\mathrm{IMP}}$, and $b l a_{\mathrm{KPC}}$, respectively (Nordman, Naas, Poirel, 2011). In Brazil, some types of carbapenemases have been detected more frequently, such as São Paulo metallo- $\beta$-lactamase (SPM) in P. aeruginosa isolates (Rossi, 2011; Rizek et al, 2014.), OXA-23 in Acinetobacter spp. isolates, and KPC in Enterobacteriaceae isolates (Rossi, 2011, Biberg et al., 2015; Rieger et al., 2016). The identification of carbepenemase production is currently the most successful way by which carbapenem resistance is determined among members of the Enterobacteriaceae family (Gupta et al., 2011). In the present study, the $b l a_{\mathrm{KPC}}$ gene was detected in $50 \%$ of the K. pneumoniae isolates, and bla ${ }_{O X A}$ was detected in all of the Acinetobacter spp. isolates. The MBL genes $\left(b l a_{\mathrm{SPM}}, b l a_{\mathrm{IMP}}, b l a_{\mathrm{GIM}}\right.$, and $\left.b l a_{\mathrm{SIM}}\right)$ were not detected in any of the isolates tested.

The phenotypic MHT test presented high sensitivity in detecting KPC-producing K. pneumonia in the present study, which was confirmed by genotypic testing. Raghunathan, Samuel, and Tibbetts (2011) reported similar results, with sensitivity as high as $90 \%$. However,
Girlich, Poirel, and Nordmann (2012) found that the phenotypic MHT test had low sensitivity in detecting other carbapenemases, particularly MBL, such as NDM.

The presence of MBL is quite common in $P$. aeruginosa. However, despite the significant resistance of the isolates to carbapenems, this enzyme was not detected by our phenotypic test. Genotypic testing, which targets the most common bacterial MBL genes that are associated with resistance, was negative. These results suggest other mechanisms of resistance, such as the direct actions of efflux pumps or the loss of porins.

The $b l a_{\text {OXA-51 }}$ gene was detected in all of the Acinetobacter spp. isolates, which may indicate that all of them belonged to the A. baumannii species, which naturally harbors this gene in its chromosome (Héritier et al., 2005). The OXA-51 family, similar to $\beta$-lactamases, comprises several members and has weak activity against carbapenems. When these enzymes are expressed in vivo, however, they can increase the MIC of carbapenems, leading to a resistant isolate. Although few studies have implicated OXA-51 in the resistance to carbapenems, these enzymes are nonetheless concerning and have been shown to confer resistance to carbapenems in $A$. baumannii (Evan, Amyes, 2014). Furthermore, over $80 \%$ of the Acinetobacter spp. isolates that were resistant to carbapenems were also positive for $b l a_{\text {OXA-23 }}$. The $b l a_{\text {OXA-23 }}$ gene is able to confer resistance to carbapenems, although high levels of resistance ( $\mathrm{MIC} \geq 32 \mu \mathrm{g} / \mathrm{mL}$ ) were observed only when $b l a_{\mathrm{OXA}-23}$ was associated with other mechanisms (Evan, Amyes, 2014).

ERIC-PCR revealed high genetic similarity among KPC-producing $K$. pneumoniae. This finding raises concerns about inadequate control in the studied hospital environment and the dissemination of multidrug-resistant bacteria. KPC-producing Enterobacteriaceae was first reported in Brazil in 2005 and has spread, becoming endemic in many hospitals (Bonelli, Moreira, Picão, 2014). A previous study in southern Brazil was based on a surveillance program for multidrug-resistant bacteria and found that KPC-producing Enterobacteriaceae increased from $17 \%$ in 2010 to over $80 \%$ in 2011 (Toledo et al., 2012). Of the KPC-producing K. pneumoniae and OXAproducing Acinetobacter spp., 12/13 (92.3\%) and 10/11 (91.0\%), respectively, belonged to the same cluster. This sharp increase in such a short period of time emphasizes the importance of this kind of antimicrobial resistance in Brazil.

\section{CONCLUSION}

High antimicrobial resistance to carbapenems, mainly by $\beta$-lactamase-producing Enterobacteriaceae 
and non-glucose-fermenting Gram-negative, was detected in isolates from patients in an ICU in southern Brazil. The genetic similarities among the KPC-producing $K$. pneumoniae isolates and among the OXA-producing Acinetobacter spp. should alert health professionals to the necessity of implementing suitable measures for infection control in this studied environment.

\section{REFERENCES}

ARAKAWA, Y.; SHIBATA, N.; SHIBAYAMA, K.; KUROKAWA, H.; YAGI, T.; FUJIWARA, H.; GOTO, $\mathrm{M}$. Convenient test for screening metallo-beta-lactamaseproducing Gram-negative bacteria by using thiol compounds. J. Clin. Microbiol., v.38, n.1, p.40-43, 2000.

BIBERG, C.A.; RODRIGUES, A.C.S.; CARMO, S.F.; CHAVES, C.E.V.; GALES, A.C.; CHANG, M.R. KPC2-producing Klebsiella pneumoniae in a hospital in the Midwest region of Brazil. Braz. J. Microbiol., v.46, n.2, p.501-4, 2015.

BONELLI, R.R.; MOREIRA, B.M.; PICÃO, R.C. Antimicrobial resistance among Enterobacteriaceae in South America: history, current dissemination status and associated social economic factors. Drug Resist. Updat., v.17, n.1-2, p.2436, 2014.

CASSIR, N.; ROLAIN, J.M.; BROUQUI, P.A. A new strategy to fight antimicrobial resistance: the revival of old antibiotics. Front Microbiol., v.5, Article:551, p.1-15, 2014.

CASTANHEIRA, M.; TOLEMAN, M.A.; JONES, R.N.; SCHMIDT, F.J.; WALSH, T.R. Molecular characterization of a $\beta$-lactamase gene, bla $_{\text {GIM- }-1}$, encoding a new subclass of metallo- $\beta$-lactamase. Antimicrob. Agents Chemother., v.48, n.12, p.4654-4661, 2004.

CHERKAOUI, A.; EMONET, S.; RENZI, G.; RIAT, A.; GREUB, G.; SCHRENZEL, J. ESBL and carbapenemases in Enterobacteriaceae. Rev. Med. Suisse, v.10, n.450, p.2142-2148, 2014.

CLINICALAND LABORATORY STANDARDS INSTITUTE.

CLSI. Performance standards for antimicrobial susceptibility. Twenty-fifth informational supplement. Document M100-S25, Wayne, USA, v.25, n.3, p.236, 2015.

EVANS, B.A.; AMYES, S.G.B. OXA $\beta$-Lactamases. Clin. Microbiol. Rev., v.27. n.2, p.241-263, 2014.
GAGLIOTTI, C.; CAPPELLI, V, CARRETTO, E.; MARCHI, M.; PAN, A.; RAGNI, P.; SARTI, M.; SUZZI, R.; TURA, G.A.; MORO, M.L.; EMILIA-ROMAGNA GROUP FOR CPE CONTROL. Control of carbapenemase-producing Klebsiella pneumoniae: a region-wide intervention. Euro Surveill., v.19, n.43, Article: 20943, 2014.

GALES, A.C.; MENEZES, L.C.; SILBERT, S.; SADER, H.S. Dissemination in distinct Brazilian regions of an epidemic carbapenem-resistant Pseudomonas aeruginosa producing SPM metallo- $\beta$-lactamase. Antimicrob. Agents Chemother., v.52, n.4, p.699-702, 2003 a.

GALES, A.C.; TOGNIM, M.C.; REIS, A.O.; JONES, R.N.; SADER, H.S. Emergence of an IMP-like metallo-enzyme in an Acinetobacter baumannii clinical strain from a Brazilian teaching hospital. Diagn. Microbiol. Infect. Dis., v.45, n.1, p.77-79, 2003b.

GASTMEIER, P.; GEFFERS, C.; BRANDT, C.; ZUSCHNEID, I.; SOHR, D.; SCHWAB, F.; BEHNKE, M.; DASCHNER, F.; RUDEN, H. Effectiveness of a nationwide nosocomial infection surveillance system for reducing nosocomial infections. J. Hosp. Infect, v. 64, n.1, p.16-22, 2006.

GIRLICH, D.; POIREL, L.; NORDMANN, P. Value of the modified Hodge test for detection of emerging carbapenemases in Enterobacteriaceae.J. Clin. Microbiol., v.50, n.2, p.477-479, 2012.

GUPTA, N.; LIMBAGO, B.M.; PATEL, J.B.; KALLEN, A.J. Carbapenem-eesistant Enterobacteriaceae: epidemiology and prevention. Clin. Infect. Dis., v.53, n.1, p.60-67, 2011.

HÉRITIER, C.; POIREL, L.; FOURNIER, P.-E.; CLAVERIE, J.-M.; RAOULT, D.; NORDMANN, P. Characterization of the naturally occurring oxacillinase of Acinetobacter baumannii. Antimicrob. Agents Chemother., v.49, n.10, p.4174-4179, 2005.

JONES, R.N.; GUZMAN-BLANCO, M.; GALES, A.C.; GALLEGOS, B.; CASTRO, A.L.; MARTINO, M.D.; VEGA, S.; ZURITA, J.; CEPPARULO, M.; CASTANHEIRA, M. Susceptibility rates in Latin American nations: report from a regional resistance surveillance program (2011). Braz. J. Infect Dis., v.17, n.6, p. 672-681, 2013. 
LANDELLE, C.; MARIMUTHU, K.; HARBARTH, S. Infection control measures to decrease the burden of antimicrobial resistance in the critical care setting. Curr. Opin. Crit. Care, v.20, n.5, p.499-506, 2014.

MARAGAKIS, L.L. Recognition and prevention of multidrugresistant Gram-negative bacteria in the intensive care units. Crit. Care Med., v.38, n.8, p.5345-5351, 2010.

MCGOWAN, J.E. Resistance in nonfermenting gram-negative bacteria: multidrug resistance to the maximum. Am. J. Med., v.119, Suppl., p.S29-36, 2006.

MENDES, C.; OPLUSTIL, C.; SAKAGAMI, E.; TURNER, P.; KIFFER, C.; MYSTIC BRAZIL GROUP. Antimicrobial susceptibility in intensive care units: MYSTIC Program Brazil 2002. Braz. J. Infect. Dis., v.9, n.1, p.44-51, 2005.

NOGUEIRA, K.S.; PAGANINI, M.C.; CONTE, A.; COGO, L.L.; REASON, T.M.; SILVA, M.J.; DALLA-COSTA, L.M. Emergence of extended-spectrum $\beta$-lactamase producing Enterobacter spp. in patients with bacteremia in a tertiary hospital in southern Brazil. Enferm. Infecc. Microbiol. Clin., v.32, n.2, p.87-92, 2014.

NORDMANN, P.; NAAS, T.; POIREL, L. Global spread of carbapenemase-producing Enterobacteriaceae. Emerg Infect Dis., v.17, n.10, p.1791-1798, 2011.

POIREL, L.; WALSH, T.R.; CUVILLIER, V.; NORDMANN, P. Multiplex PCR for detection of acquired carbapenemasegenes. Diag. Microbiol. Infect. Dis., v.70, n.1, p.119-123, 2011.

POULOU, A.; GRIVAKOU, E.; VRIONI, G.; KOUMAKI, V.; PITTARAS, T.; POURNARAS, S.; TSAKRIS, A. Modified CLSI extended-spectrum $\beta$-lactamase (ESBL) confirmatory test for phenotypic detection of ESBLs among Enterobacteriaceae producing various $\beta$-lactamases. $J$. Clin. Microbiol., v.52, n.5, p.1483-9, 2014.

RAGHUNATHAN, A.; SAMUEL, L.; TIBBETTS, R.J. Evaluation of a real-time PCR assay for the detection of the Klebsiella pneumoniae carbapenemase genes in microbiological samples in comparison with the modified Hodge test. Am. J. Clin. Pathol., v.135, n.4, p.566-571, 2011.
RIEGER,A.; MOHR, G.; VARGAS DA SILVA, L.; FERNANDO DE OLIVEIRA, C.; PEREIRA DA ROCHA, M. Update on monitoring the spread of KPC carbapenemase-producing Klebsiella spp. in South Brazil. J. Hosp. Infect., v.92, n.1, p.107-8, 2016.

RIZEK, C.; FU, L.; DOS SANTOS, L.C.; LEITE, G.; RAMOS, J.; ROSSI, F.; GUIMARAES, T.; LEVIN, A.S.; COSTA, S.F. Characterization of carbapenem-resistant Pseudomonas aeruginosa clinical isolates, carrying multiple genes coding for this antibiotic resistance. Ann. Clin. Microbiol. Antimicrob., v.2, p.13-43, 2014.

ROSENTHAL, V.D.; MAKI, D.G.; GRAVES, N. The International Nosocomial Infection Control Consortium (INICC): Goal and objectives, description of surveillance methods, and operational activities. Am. J. Infect. Control, v.36, n.9, p.1-12, 2008.

ROSSI, F. The challenges of antimicrobial resistance in Brazil. Clin. Infect. Dis., v.52, n.9, p.1138-1143, 2011.

SNEATH, P.H.A.; SOKAL, R.R. Numerical taxonomy: the principles and practice of numerical classification. San Francisco: WH Freeman and Co., 1973. p.573.

STUART, J.C.; LEVERSTEIN-VAN HALL, M.A. Guideline for phenotypic screening and confirmation of carbapenemases in Enterobacteriacea. Int. J. Antimicrob. Agents, v.36, n.2, p.205-210, 2010.

SWANENBURG, M.; URLINGS, H.A.P.; KEUZENKAMP, D.A.; SNIJDERS, J.M.A. Validation of ERIC PCR as a tool in epidemiologic research of Salmonella in slaughter pigs. J. Ind. Microbiol. Biotechnol., v.21, p.141-144, 1998.

SYDNOR, E.R.M.; PERL, T.M. Hospital Epidemiology and Infection Control in Acute-Care Settings. Clin. Microbiol. Rev., v.24, n.1, p.141-173, 2011.

SZCZUKA, E.; KAZNOWSKI, A. Typing of clinical and environmental Aeromonas sp. strains by random amplified polymorphic DNA PCR, repetitive extragenic palindromic $\mathrm{PCR}$, and enterobacterial repetitive intergenic consensus sequence PCR PCR. J. Clin. Microbiol., v.42, n.1, p.220$228,2004$. 
TÄNGDÉN; T., GISKE, C.G. Global dissemination of extensively drug-resistant carbapenemase-producing Enterobacteriaceae: clinical perspectives on detection, treatment and infection control. J. Intern. Med., v.277, n.5, p.501-512, 2015.

TOLEDO, P.V.M.; AREND, L.N.; PILONETTO, M.; COSTA OLIVEIRA, J.C.; LUHM, K.R.; WORKING GROUP IN HEALTHCARE ASSOCIATED INFECTIONS (WGHAI). Working Group in Healthcare Associated Infections (WGHAI). Surveillance programme for multidrug-resistant bacteria in healthcare-associated infections: an urban perspective in South Brazil. J. Hosp. Infect., v.80, n.4, p.351-353, 2012.

TUMBARELLO, M.; CITTON, R.; SPANU,T.; SANGUINETTI, M.; ROMANO, L.; FADDA, G.; CAUDA, R. ESBL-producing multidrug-resistant Providencia stuartii infections in a university hospital. $J$. Antimicrob. Chemother., v.53, n.2, p.277-282, 2004.

VERSALOVIC, J.; KOEUTH, T.; LUPSKI, J.R. Distribution of repetitive DNA sequences in Eubacteria and application to fingerprinting of bacterial genomes. Nucleic Acid Res., v.19, p.6823-6831, 1991.
WOODFORD, N.; ELLINGTON, M.J.; COELHO, J.M.; TURTON, J.F.; WARD, M.E.; BROWN, S.; AMYES, S.G.; LIVERMORE, D.M. Multiplex PCR for genes encoding prevalent OXA carbapenemases in Acinetobacter spp. Int. J. Antimicrob. Agents, v.27, n.4, p.351-353, 2006.

YAN, J.; HSUEH, P.R.; KO, W.C.; LUH, K.T.; TSAI, S.H.; WU, H.M.; WU, J.J. Metallo- $\beta$-lactamase in clinical Pseudomonas isolates in Taiwan and identification of VIM3, a novel variant of the VIM-2 enzyme. Antimicrob. Agents Chemother., v.45, n.8, p.2224-2228, 2001.

ZAVASCKI, A.P.; MACHADO, A.B.; OLIVEIRA, K.R.; SUPERTI, S.V.; PILGER, D.A.; CANTARELLI, V.V.; PEREIRA, P.R.; LIEBERKMECHT, A.C.; BARTH, A.L. KPC-2-producing Enterobacter cloacae in two cities from southern Brazil. Int. J. Antimicrob. Agents, v.34, n.3, p.286288, 2009.

Received for publication on $16^{\text {th }}$ June 2016 Accepted for publication on $15^{\text {th }}$ February 2017 